\title{
Facilitation by Endogenous Tachykinins of the NMDA-Evoked Release of Acetylcholine after Acute and Chronic Suppression of Dopaminergic Transmission in the Matrix of the Rat Striatum
}

\author{
Marie-Louise Kemel,, ${ }^{1}$ Sylvie Pérez, ${ }^{1}$ Gérard Godeheu, ${ }^{1}$ Philippe Soubrié, ${ }^{2}$ and Jacques Glowinski ${ }^{1}$ \\ 1 Institut National de la Santé et de la Recherche Médicale U114, Collège de France, 75231 Paris, France, and 2Sanofi \\ Recherche, 34184 Montpellier, France
}

Using a microsuperfusion method in vitro, the effects of the $\mathrm{NK}_{1}, \mathrm{NK}_{2}$, and $\mathrm{NK}_{3}$ tachykinin receptor antagonists SR140333, SR48968, and SR142801, respectively, on the NMDA-evoked release of $\left[{ }^{3} \mathrm{H}\right]$-acetylcholine were investigated after both acute and chronic suppression of dopamine transmission in striosomes and matrix of the rat striatum. NMDA (1 mM) alone or with D-serine $(10 \mu \mathrm{M})$ in the presence of $\alpha$-methyl- $p$-tyrosine $(100 \mu \mathrm{M})$ markedly enhanced the release of $\left[{ }^{3} \mathrm{H}\right]$-acetylcholine through a dopamine-independent inhibitory process. In both conditions, as well as after chronic 6-OHDA-induced denervation of striatal dopaminergic fibers, SR140333, SR48968, or SR142801 (0.1 $\mu \mathrm{M}$ each) reduced the NMDA-evoked release of $\left[{ }^{3} \mathrm{H}\right]$-acetylcholine in the matrix but not in striosome-enriched areas. These responses were selectively abolished by coapplication with NMDA of the respective tachykinin agonists, septide, $\left[\right.$ Lys $\left.^{5}, \mathrm{MeLeu}^{9}{ }, \mathrm{Nle}^{10}\right] \mathrm{NKA}(4-10)$, or senktide. Distinct mechanisms are involved in the effects of the tachykinin antagonists because the inhibitory response of SR140333 was addi- tive with that of either SR48968 or SR142801. In addition, the SR140333-evoked response remained unchanged, whereas those of SR48968 and SR142801 were abolished in the presence of $N^{G}$-monomethyl-L-arginine (nitric oxide synthase inhibitor).

Therefore, in the matrix but not in striosomes, the acute or chronic suppression of dopamine transmission unmasked the facilitatory effects of endogenously released substance $P$, neurokinin $A$, and neurokinin $B$ on the NMDA-evoked release of $\left[{ }^{3} \mathrm{H}\right]$-acetylcholine. Whereas substance $P$ and neurokinin $A$ are colocalized in same efferent neurons, their responses involve distinct circuits because the substance $P$ response seems to be mediated by $\mathrm{NK}_{1}$ receptors located on cholinergic interneurons, while those of neurokinin $A$ and neurokinin $B$ are nitric oxide-dependent.

Key words: tachykinin receptor antagonists; NMDA; acetylcholine release; acute and chronic suppression of dopamine transmission; matrix compartment; striatum
The two main compartments of the striatum, the striosomes and the matrix, which can be distinguished by the origin of their afferent and efferent pathways, are connected to limbic and sensorimotor systems, respectively (Graybiel, 1990; Gerfen and Wilson, 1996). The striatal cholinergic interneurons, which are innervated by thalamic and cortical neurons, are tonically active (Aosaki et al., 1995). Their cell bodies are present in higher density in the matrix close to the striosomes, and their neurites innervate both compartments (Graybiel et al., 1986; Blanchet al., 1997). Thus, these interneurons could contribute to the transfer of information from striosomes to the matrix in which their main targets are the striatal efferent neurons (Kemel et al., 1992; Bernard et al., 1993; Calabresi et al., 2000). Indicating further the role of these cholinergic interneurons in striatal functions, antimuscarinic agents were shown to ameliorate motor abnormalities in Parkinson's disease (Olanow and Koller, 1998) and to reduce neuroleptic-induced catalepsy (Anderson et al., 1995).

Substance P (SP), neurokinin (NK) A, and NKB, the endogenous ligands of $\mathrm{NK}_{1}, \mathrm{NK}_{2}$, and $\mathrm{NK}_{3}$ tachykinin receptors, are

Received Aug. 23, 2001; revised Oct. 30, 2001; accepted Dec. 6, 2001.

This work was supported by Institut National de la Santé et de la Recherche Médicale, Collège de France, and a grant from Sanofi-Synthelabo-Recherche. We are grateful to A. Auclair for her valuable advice in preparing lesioned animals and HPLC estimation of dopamine levels.

Correspondence should be addressed to Marie-Louise Kemel, Institut National de la Santé et de la Recherche Médicale U114, Collège de France, 11 place Marcelin Berthelot, 75231 Paris, France. E-mail: marie-lou.kemel@collège-de-france.fr. Copyright (C) 2002 Society for Neuroscience 0270-6474/02/221929-08\$15.00/0 colocalized with GABA in striatal efferent GABAergic neurons. SP-containing terminals originating from recurrent collaterals of these neurons make synaptic contacts with cholinergic interneurons (Bolam and Bennett, 1995). In striosomes, the three tachykinins are present in neurons innervating the substantia nigra pars compacta. In the matrix, SP and NKA are located in neurons projecting to the substantia nigra pars reticulata and the entepodoncular nucleus, whereas NKB is found in neurons innervating the external globus pallidus (Besson et al., 1990; Gerfen and Wilson, 1996).

Exogenous agonists of $\mathrm{NK}_{1}, \mathrm{NK}_{2}$, or $\mathrm{NK}_{3}$ tachykinin receptors stimulate the release of acetylcholine $(\mathrm{ACh})$ from the rat striatum (Arenas et al., 1991; Petitet et al., 1991; Guevara-Guzman et al., 1993; Steinberg et al., 1995). Endogenously released tachykinins facilitate the release of $\mathrm{ACh}$ through their action on $\mathrm{NK}_{1}$ (Anderson et al., 1994) and $\mathrm{NK}_{2}$ (Steinberg et al., 1998b) receptors. In these studies, endogenous tachykinins are released in vivo by stimulation of dopamine (DA) $\mathrm{D}_{1}$ receptors with either exogenous agonists or neurotensin-induced endogenous release of DA, in the latter situation tachykinin regulations being observed only after the blockade of $\mathrm{D}_{2}$ receptors (Steinberg et al., 1998b). We have also shown in vitro that endogenous SP and NKA are released under potent stimulation of NMDA receptors (Blanchet et al.2000) and that both tachykinins indirectly inhibit the release of ACh through a DA-dependent process. However, in contrast, in the matrix, under the blockade of DA transmission, SP and 
NKA were shown to facilitate the NMDA-evoked release of ACh (Blanchet et al., 1998).

To further clarify the role of the neuromodulators SP, NKA, and NKB on the NMDA-evoked release of ACh in the striatum, we have applied the tachykinin receptor antagonists SR140333 $\left(\mathrm{NK}_{1}\right)$, SR48968 $\left(\mathrm{NK}_{2}\right)$, and SR142801 $\left(\mathrm{NK}_{3}\right)$, in vitro in both compartments of the rat striatum. This was achieved after the acute blockade of DA transmission but also 1 month after the 6-hydroxydopamine (6-OHDA)-induced degeneration of the striatal DA innervation, a chronic situation generally used as an experimental model for Parkinson's disease.

\section{MATERIALS AND METHODS}

Experiments were performed on Sprague Dawley male rats (200-250 gm; Charles River, Iffa Credo, France) kept for at least $8 \mathrm{~d}$ in a controlled environment of light (8:00 A.M., 8:00 P.M.), temperature, and humidity. Animals were killed by decapitation during the light period.

6-hydroxydopamine injections into the fields of Forel. Thirty minutes before operation, animals received an intraperitoneal injection of desipramine $(25 \mathrm{mg} / \mathrm{kg})$ to protect the ascending noradrenergic pathways. Rats (150-175 gm) were lesioned under ketamine anesthesia (Imalgene R; Iffamerieux; $150 \mathrm{mg} / \mathrm{kg}$, i.p.) using a David Kopf stereotaxic apparatus (incisor bar $3.4 \mathrm{~mm}$ above the interaural line). A microinjection cannula was implanted into the right fields of Forel at the following coordinates: $2.2 \mathrm{~mm}$ caudal to bregma, $1.6 \mathrm{~mm}$ lateral to the midline, and $8.4 \mathrm{~mm}$ under the surface of the skull. 6-OHDA was dissolved in saline containing $0.02 \%$ ascorbic acid and injected at a dose of $6 \mu \mathrm{g}$ in a volume of $1.5 \mu \mathrm{l}$ over $5 \mathrm{~min}$.

One month after the lesion, release experiments were performed as described below, and the efficacy of the lesion was tested by the estimation of dopamine levels in the striatum. In each hemisphere, a sagittal slice $(500 \mu \mathrm{m})$ was cut in the central part of the striatum (between slices used for striosomes and matrix release experiments), and a microdisk of tissue $(1.2 \mathrm{~mm}$ diameter; $\sim 43 \mu \mathrm{g}$ of protein) was dissected and stored at $-20^{\circ} \mathrm{C}$ in $150 \mu \mathrm{l}$ of $0.1 \mathrm{~N}$ perchloric acid containing $0.05 \%$ sodium metabisulfite. After homogenization and centrifugation $(20,000 \times g, 15$ min), fractions of supernatants $(8 \mu \mathrm{l})$ were injected into an HPLC column $(80 \times 4.6 \mathrm{~mm}, 3 \mu \mathrm{m}$ particle size; HR-80; ESA Inc., Chelmsford, MA) equilibrated with a mobile phase. Mobile phase $\left(\mathrm{NaH}_{2} \mathrm{PO}_{4}, 75 \mathrm{~mm}\right.$; EDTA, $20 \mu \mathrm{M}$; octane sulfonic acid, $2.75 \mathrm{~mm}$; triethylamine, $0.7 \mathrm{~mm}$; acetonitrile $6 \%$; methanol $6 \%, \mathrm{pH} 5.2$ ) was delivered at $0.7 \mathrm{ml} / \mathrm{min}$ by an ESA-580 pump. Electrochemical detection was performed with an ESA coulometric detector (Coulochem II 5100A, with a 5014A analytical cell; Eurosep, Cergy, France). The conditioning and detecting electrodes were respectively set at -0.175 and $+0.175 \mathrm{mV}$, allowing a good signalto-noise ratio of the dopamine oxidization current. External standards were used to determine the sensitivity stability (0.3-0.5 pg of dopamine) (Darracq et al. 2001). Only those animals with striatal DA levels decreased by $>92 \%$ were kept for further analysis.

Determination of striosome- and matrix-enriched areas on slices of the rat striatum. As previously described (Desban et al., 1993), striosome- and matrix-enriched areas (denominated striosomes and matrix for simplification) were delineated on sagittal brain sections after autoradiographic visualization of $\left[{ }^{3} \mathrm{H}\right]$-naloxone binding to $\mu$-opiate receptors, a specific marker of striosomes (Herkenham and Pert, 1981). [ $\left.{ }^{3} \mathrm{H}\right]-$ Naloxone binding exhibited a patchy distribution with highly labeled striosomes contrasting with weakly labeled matrix. A prominent striosomes territory was observed in the rostral pole of the striatum, and an extensive unlabeled matrix area was detected on most lateral sagittal sections. Lateral and medial sagittal slices were thus used to superfuse matrix $(4<$ $\mathrm{L}<5$ according to the atlas of Paxinos and Watson, 1986) and striosomes $(2<\mathrm{L}<3)$ areas, respectively.

Superfusion experimental device. The superfusion was performed as previously described (Krebs et al., 1991). Briefly, brains were rapidly removed and placed into a cool artificial CSF (ACSF). In each hemisphere, two sagittal slices $(1.2-1.5 \mathrm{~mm})$ were cut with a vibratome at the appropriate laterality, one for the striosomes $(2<\mathrm{L}<3)$, and the other for the matrix $(4<\mathrm{L}<5)$. Slices were then placed into a superfusion chamber containing ACSF maintained at $34^{\circ} \mathrm{C}$, saturated with $\mathrm{O}_{2}$ and $\mathrm{CO}_{2}(95: 5, \mathrm{v} / \mathrm{v})$, and continuously renewed $(750 \mu \mathrm{l} / \mathrm{min})$ thanks to a peristaltic pump. Microsuperfusion cannulas were vertically placed onto each selected area of the slices using micromanipulators and a dissecting microscope. These microsuperfusion devices consisted of a guide placed at the surface of the tissue and two inner tubes, one penetrating slightly into the slice $(200 \mu \mathrm{m})$ to deliver the surperfusion fluid, and the other situated $5 \mathrm{~mm}$ above the tissue to collect superfusates. An oxygenated ACSF was continuously delivered through each superfusion device using another peristaltic pump. This procedure allows the superfusion of a limited volume of tissue $\left(\sim 0.5 \mathrm{~mm}^{3}\right)$ surrounding the inner tube of the microsuperfusion device. As previously discussed, the area superfused on medial slices corresponds to a striosome-enriched area slightly contaminated $(\sim 25 \%)$ by matrix tissue, whereas the area superfused on lateral slices corresponds only to matrix tissue (Krebs et al., 1991; Blanchet et al., 1997).

Estimation of $\left[{ }^{3} \mathrm{H}\right]-A C h$ release. The release of $\left[{ }^{3} \mathrm{H}\right]$-ACh synthesized from $\left[{ }^{3} \mathrm{H}\right]$-choline was estimated as previously described (Scatton and Lehmann, 1982; Blanchet et al., 1997). This procedure is based on the specific transport (through a high-affinity uptake system) of $\left[{ }^{3} \mathrm{H}\right]$-choline into cholinergic interneurons and the synthesis of $\left[{ }^{3} \mathrm{H}\right]$-ACh. Briefly, the labeling period consisted of a $20 \mathrm{~min}(30 \mu \mathrm{l} / \mathrm{min})$ delivery of the ACSFenriched in $\left[{ }^{3} \mathrm{H}\right]$-choline $(81 \mathrm{Ci} / \mathrm{mmol} ; 0.05 \mu \mathrm{M}$; NEN, Boston, MA). Because the NMDA-evoked release of $\left[{ }^{3} \mathrm{H}\right]$-ACh is only observed in the absence of magnesium, the tissue was then washed for $35 \mathrm{~min}$ using the magnesium-free ACSF (60 $\mu \mathrm{l} / \mathrm{min})$ enriched in hemicholinium-3 (10 $\mu \mathrm{M})$, a specific inhibitor of the high-affinity choline uptake process. The release period $(50 \mathrm{~min})$ consisted of the constant delivery $(60 \mu \mathrm{l} / \mathrm{min})$ of the superfusion medium used during the washing period. Receptor antagonists, DA or nitric oxide (NO) synthase inhibitors were added throughout the washing and the release periods while NMDA with or without D-serine and tachykinin agonists were applied for a 2 min period $35 \mathrm{~min}$ after the beginning of the superfusion (release period). Superfusates were collected in 5 min serial fractions.

Released $\left[{ }^{3} \mathrm{H}\right]-\mathrm{ACh}$ is rapidly hydrolyzed and generates $\left[{ }^{3} \mathrm{H}\right]$-choline, whose high-affinity transport into cholinergic interneurons is prevented by hemicholinium-3. [ ${ }^{3} \mathrm{H}$ ]-Choline was estimated in $200 \mu \mathrm{l}$ aliquots of 5 min superfusate fractions. At the end of the $50 \mathrm{~min}$ superfusion, superfused tissues (striosomes or matrix) were punched out from slices and dissolved in $200 \mu \mathrm{l}$ of $\mathrm{HCl} 0.1 \mathrm{~N} 0.1 \%$ Triton for the estimation of total radioactivity. Because variations in the amount of incorporated $\left[{ }^{3} \mathrm{H}\right]$ choline were observed from slices of different animals, the amount of $\left[{ }^{3} \mathrm{H}\right]$-choline recovered in each successive superfusate fraction was expressed as a percentage of the calculated radioactivity present in the tissue during the time interval corresponding to the collected fraction [fractional release (FR)]. The spontaneous release of $\left[{ }^{3} \mathrm{H}\right]-\mathrm{ACh}(\mathrm{FR})$ was estimated during the two fractions preceding the NMDA application and the NMDA-evoked release of $\left[{ }^{3} \mathrm{H}\right]$-ACh in each successive fraction was then expressed as a percentage of the average spontaneous release of the labeled transmitter. The average incorporation of $\left[{ }^{3} \mathrm{H}\right]$-choline was $\sim 1.5$ times higher in matrix-enriched $(2230 \pm 180 \mathrm{~Bq})$ than in striosomeenriched $(1650 \pm 20 \mathrm{~Bq})$ areas, but no statistical difference was found for the spontaneous FR of $\left[{ }^{3} \mathrm{H}\right]-\mathrm{ACh}$ release between the striosomes $(2.8 \pm$ $0.1)$ and the matrix $(2.7 \pm 0.1)$.

In each experiment, positions of superfused areas were checked and compared with the localization of striosomes as determined from autoradiographic data obtained after $\left[{ }^{3} \mathrm{H}\right]$-naloxone binding on sections cut at the same laterality in distinct animals. Variations in these positions were of $\pm 250 \mu \mathrm{m}$.

Pharmacological treatments. The artificial ACSF had the following composition (in mM): $\mathrm{NaCl}, 126.5 ; \mathrm{NaHCO}_{3}, 27.5 ; \mathrm{KCl}, 2.4 ; \mathrm{MgCl}_{2}, 0.83$; $\mathrm{KH}_{2} \mathrm{PO}_{4}, 0.5 ; \mathrm{CaCl}_{2}, 1.1 ; \mathrm{Na}_{2} \mathrm{SO}_{4}, 0.5$; and glucose, 11.8 . When added, (-)sulpiride, $\alpha$-methyl- $p$-tyrosine $\left(\alpha\right.$-MPT), $N^{\mathrm{G}}$-monomethyl-L-arginine (L-NMMA), the $\mathrm{NK}_{1}, \mathrm{NK}_{2}$, and $\mathrm{NK}_{3}$ tachykinin receptor antagonists SR140333, SR48968, and SR142801, respectively, and their antipodes SR140603, SR48965, and SR142806, respectively, were applied at the onset of the washing period, up to the end of the superfusion. Finally, NMDA with or without D-serine was applied for $2 \mathrm{~min}, 70 \mathrm{~min}$ after the beginning of the washing period. When used, the $\mathrm{NK}_{1}, \mathrm{NK}_{2}$, and $\mathrm{NK}_{3}$ tachykinin receptor agonists, septide, $\left[\mathrm{Lys}^{5}, \mathrm{MeLeu}^{9}, \mathrm{NorLe}^{10}\right] \mathrm{NKA}_{4-10}$ and senktide, respectively, were applied 2 min with NMDA. NMDA, D-serine, hemicholinium-3, $\alpha$-MPT, (-)sulpiride, and L-NMMA were obtained from Sigma (St. Louis, MO); SR140333, SR48968, SR142801, SR140603, SR48965, and SR142806 were kindly given by Sanofi Recherche. Silicon catheters of peristaltic pumps were often changed to avoid artifacts caused by an eventual adsorption of the drugs to these catheters.

Statistical analysis. Differences between treatments were evaluated with the two-tailed Student's $t$ test. When multiple comparisons were made, results were analyzed using one-way ANOVA. Individual comparisons between treatments were evaluated with the multiple com- 
Table 1. Effects of sulpiride and of $\alpha$-methyl-p-tyrosine on the release of $\left[{ }^{3} \mathrm{H}\right]$-acetylcholine evoked by NMDA with or without $\mathrm{D}$-serine in striatal compartments

\begin{tabular}{lll} 
& $\begin{array}{l}\text { Striosome- } \\
\text { enriched areas } \\
(\%)\end{array}$ & $\begin{array}{l}\text { Matrix } \\
(\%)\end{array}$ \\
\hline NMDA $1 \mathrm{~mm}^{a}$ & $345 \pm 24$ & $270 \pm 10$ \\
+ Sulpiride $1 \mu \mathrm{M}$ & $331 \pm 37$ & $277 \pm 19$ \\
NMDA $1 \mathrm{mM} / \mathrm{D}-$ Ser & $189 \pm 6$ & $183 \pm 7$ \\
$+\alpha$ MPT $100 \mu \mathrm{M}$ & $353 \pm 26^{*}$ & $268 \pm 13^{*}$
\end{tabular}

Experiments were performed on sagittal slices of the rat brain, in either striosomeenriched areas or the matrix of the striatum, as described in Materials and Methods. NMDA ( $1 \mathrm{~mm}$ alone or with $10 \mu \mathrm{M}$ D-serine) was applied for $2 \mathrm{~min}, 70 \mathrm{~min}$ after the beginning of the washing period. When used, $(-)$ sulpiride $(1 \mu \mathrm{M})$ or $\alpha$-methyl- $p$ tyrosine $(\alpha \mathrm{MPT} ; 100 \mu \mathrm{M})$ was added to the ACSF from the start of the washing period up to the end of the experiment. In each experiment, the NMDA-evoked release of $\left[{ }^{3} \mathrm{H}\right]-\mathrm{ACh}$ was estimated in $5 \mathrm{~min}$ fractions and expressed as a percentage of the mean spontaneous release determined in the two fractions collected before NMDA application. Results are the means \pm SEM of data obtained in 15-21 experiments. ${ }^{*} p<0.05$ when the effect of NMDA + D-Ser in the presence of $\alpha$ MPT was compared with the response induced by NMDA + D-Ser alone in each striatal compartment.

${ }^{a}$ Data from Blanchet et al. (2000).

parisons Tukey test or Dunnett's test. The level of significance was set at $p<0.05$.

\section{RESULTS}

Reduction by SR140333, SR48968, or SR142801 of the NMDA-evoked release of $\left[{ }^{3} \mathrm{H}\right]-A C h$ in the matrix under the acute suppression of the dopamine inhibitory regulation

We have previously shown in both striatal compartments that in absence of magnesium, the stimulation of NMDA receptors increases the release of DA (Krebs et al., 1991) and that endogenously released DA exerts a marked inhibitory effect on the release of ACh (Blanchet et al., 1997). As illustrated in Table 1, the release of $\left[{ }^{3} \mathrm{H}\right]-\mathrm{ACh}$ evoked by potent stimulation of NMDA receptors (2 min application of $1 \mathrm{mM}$ NMDA and $10 \mu \mathrm{M}$ D-serine, in the absence of magnesium) was markedly enhanced in striosomes as well as in the matrix when DA synthesis was acutely inhibited by the coapplication of $100 \mu \mathrm{M} \alpha$-MPT. In contrast, this DA inhibitory regulation was not observed when NMDA receptors were stimulated with NMDA in the absence of D-serine, probably because of a low level of DA release. Hence, responses induced by NMDA alone were identical to those evoked by NMDA + D-serine in the presence of $\alpha$-MPT. In addition, NMDA-evoked responses were not affected by sulpiride $(1 \mu \mathrm{M})$, an antagonist of $\mathrm{D} 2$ receptors.

Thus, to further explore the regulatory role of endogenous tachykinins on the NMDA-evoked release of $\left[{ }^{3} \mathrm{H}\right]$-ACh in absence of the DA inhibitory control, NMDA receptors were stimulated by either $1 \mathrm{~mm}$ NMDA (NMDA) or $1 \mathrm{~mm}$ NMDA +10 $\mu \mathrm{M}$ D-serine in the presence of $100 \mu \mathrm{M} \alpha$-MPT (NMDA + D-serine $+\alpha$-MPT). In both situations, when used at $0.1 \mu \mathrm{M}$ but not at $10 \mathrm{~nm}$, the selective NK1 (SR140333), NK2 (SR48968), and NK3 (SR142801) tachykinin receptor antagonists decreased the evoked release of $\left[{ }^{3} \mathrm{H}\right]-\mathrm{ACh}$ in the matrix but were without effect in striosomes. In the matrix, responses induced by each tachykinin antagonist were of similar amplitude whatever the paradigm used for the stimulation of NMDA receptors, either NMDA alone or NMDA + D-serine $+\alpha$-MPT (Fig. 1). As a control, the inactive isomers of SR140333, SR48968, and SR142801

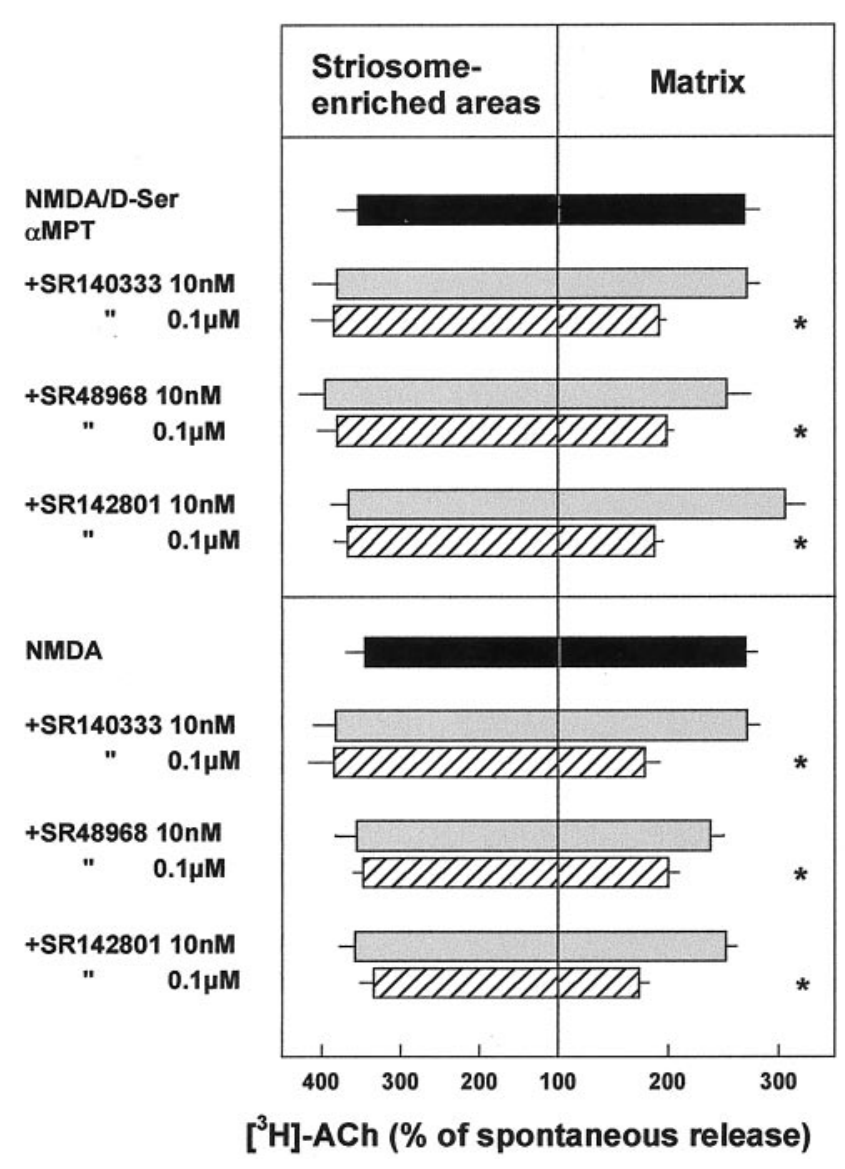

Figure 1. Effects of SR140333, SR48968, or SR142801 on the NMDAevoked release of $\left[{ }^{3} \mathrm{H}\right]-\mathrm{ACh}$ in absence of the dopamine inhibitory control of cholinergic interneurons in striatal compartments. Superfusion experiments and expression of data were performed as described in Materials and Methods and in Table 1 legend. NMDA (1 mM alone or with $10 \mu \mathrm{M}$ D-serine) was applied for $2 \mathrm{~min}, 70 \mathrm{~min}$ after the beginning of the washing period. When used, $\alpha$-MPT $(100 \mu \mathrm{M})$, SR140333, SR48968, or SR142801 (10 nM or $0.1 \mu \mathrm{M}$ for each) were added to the ACSF from the start of the washing period up to the end of the experiment. Results are the means \pm SEM of data obtained in $8-25$ experiments. ${ }^{*} p<0.05$ when NMDA responses ( $1 \mathrm{~mm}$ alone or with D-serine and $\alpha$-MPT) obtained in the presence of $\mathrm{NK}_{1}$ (SR140333), $\mathrm{NK}_{2}$ (SR48968), or $\mathrm{NK}_{3}$ (SR142801) receptor antagonists were compared with the respective effects of NMDA treatments in the absence of the tachykinin antagonists in the matrix.

(SR140603, SR48965, and SR142806, respectively) were applied to the slice at the active concentration $(0.1 \mu \mathrm{M})$ and did not reduce the evoked release of $\left[{ }^{3} \mathrm{H}\right]-\mathrm{ACh}$ in the matrix (data not shown). Thus, the increase in $\mathrm{ACh}$ release brought about by NMDA stimulation is reduced by blockade of NK1, NK2, and NK3 tachykinin receptors when DA transmission is acutely disrupted in the matrix but not in the striosomes of the striatum.

Reduction by SR140333, SR48968, or SR142801 of the NMDA-evoked release of $\left[{ }^{3} \mathrm{H}\right]-A C h$ in the matrix after chronic 6-OHDA-induced dopamine denervation of the striatum

Because 6-OHDA-induced degeneration of dopaminergic nigrostriatal neurons is generally used as an experimental model for Parkinson's disease, the involvement of endogenous tachykinins in the regulation of the evoked release of $\mathrm{ACh}$ was investigated in this model. The effects of SR140333 (NK1), SR48968 (NK2), and 
Table 2. Effects of SR140333, SR48968, or SR142801 on the NMDAevoked release of $\left[{ }^{3} \mathrm{H}\right]-\mathrm{ACh}$ in matrix and striosomes after chronic 6OH-DA-induced dopaminergic denervation of the striatum

\begin{tabular}{|c|c|c|c|}
\hline & \multicolumn{2}{|l|}{ Matrix } & \multirow{2}{*}{$\begin{array}{l}\text { Striosomes } \\
\text { 6-OHDA- } \\
\text { lesioned } \\
(\%)\end{array}$} \\
\hline & $\begin{array}{l}\text { Unlesioned } \\
(\%)\end{array}$ & $\begin{array}{l}\text { 6-OHDA- } \\
\text { lesioned } \\
(\%)\end{array}$ & \\
\hline NMDA/D-serine & $204 \pm 11$ & $279 \pm 29$ & $290 \pm 7$ \\
\hline$+\mathrm{SR} 1403330.1 \mu \mathrm{M}$ & $179 \pm 13$ & $180 \pm 10^{*}$ & $297 \pm 18$ \\
\hline$+\mathrm{SR} 489680.1 \mu \mathrm{M}$ & $279 \pm 8^{*}$ & $201 \pm 3^{*}$ & $281 \pm 17$ \\
\hline$+\mathrm{SR} 1428010.1 \mu \mathrm{M}$ & $267 \pm 30^{*}$ & $171 \pm 22^{*}$ & $281 \pm 16$ \\
\hline
\end{tabular}

One month after the 6-OH-DA injection into the fields of Forel, superfusion experiments and expression of data were performed as described in Materials and Methods and in Table 1 legend. NMDA $1 \mathrm{~mm}+10 \mu \mathrm{M}$ D-serine was applied for 2 min, $70 \mathrm{~min}$ after the beginning of the washing period. When used, SR140333, SR48968, or SR142801 ( $0.1 \mu \mathrm{m}$ for each) was added to the ACSF from the start of the washing period up to the end of the experiment. Results are the means \pm SEM of data obtained in four to six experiments. ${ }^{*} p<0.05$ when NMDA responses obtained in the presence of $\mathrm{NK}_{1}$ (SR140333), $\mathrm{NK}_{2}$ (SR48968), or $\mathrm{NK}_{3}$ (SR142801) receptor antagonists were compared with the respective effect of NMDA in the absence of the tachykinin antagonists in the matrix.

SR142801 (NK3) tachykinin antagonists on the NMDA-evoked release of $\left[{ }^{3} \mathrm{H}\right]-\mathrm{ACh}$ were examined in both striatal compartments after chronic 6-OHDA-induced DA denervation of the striatum. In this chronic condition, as observed under the acute suppression of the striatal DA transmission, the NMDA $(1 \mathrm{mM})+$ D-serine $(10 \mu \mathrm{M})$-evoked release of $\left[{ }^{3} \mathrm{H}\right]$-ACh was markedly enhanced in both the matrix $(+179 \pm 2 \%$ vs $+104 \pm 11 \%$ of the spontaneous release in unlesioned matrix) and the striosomes $(+190 \pm 7 \%$ vs $+89 \pm 6 \%$ of the spontaneous release in unlesioned striosomes). In the unlesioned matrix, the NMDA + D-serine-evoked release of $\left[{ }^{3} \mathrm{H}\right]$-ACh was enhanced in the presence of either SR48968 $(0.1 \mu \mathrm{M})$ or SR142801 $(0.1 \mu \mathrm{M})$ but not in the presence of SR140333 $(0.1 \mu \mathrm{M})$. In contrast, in the DAlesioned matrix, the NMDA + D-serine-evoked release of ACh was significantly reduced in the presence of each of the three antagonists. The three tachykinin antagonists were without effect in DA-lesioned striosomes (Table 2). Thus, as observed in the acute preparation, blockade of NK1, NK2, and NK3 receptors lead to a reduction of ACh release resulting from NMDA stimulation in the matrix, but not the striosomes of the striatum from rats chronically deprived of DA.

\section{Reversal by selective tachykinin agonists of the reduction of the NMDA-evoked release of $\left[{ }^{3} \mathrm{H}\right]-\mathrm{ACh}$ induced by the $\mathrm{NK}_{1}, \mathrm{NK}_{2}$, and $\mathrm{NK}_{3}$ tachykinin receptor antagonists in the matrix}

To confirm that the responses induced in the matrix by the tachykinin receptor antagonists resulted indeed from the selective blockade of $\mathrm{NK}_{1}, \mathrm{NK}_{2}$, or $\mathrm{NK}_{3}$ tachykinin receptors, attempts were made to counteract the effects of these antagonists by the coapplication with NMDA + D-serine of the respective selective receptor agonists; septide (NK1), $\left[\mathrm{Lys}^{5}, \mathrm{MeLeu}^{9}, \mathrm{NLe}^{10}\right.$ ] $\mathrm{NKA}(4-10)$ (NK2), or senktide (NK3). Although each agonist alone $(0.1 \mu \mathrm{M}$ each $)$ was without effect on the NMDA + D-serine $+\alpha$-MPT-evoked release of $\left[{ }^{3} \mathrm{H}\right]-\mathrm{ACh}$, septide, [Lys $\left.{ }^{5}, \mathrm{MeLeu}^{9}, \mathrm{NLe}^{10}\right] \mathrm{NKA}(4-10)$, and senktide completely counteracted the reduction of the evoked release of $\left[{ }^{3} \mathrm{H}\right]-\mathrm{ACh}$ induced by SR140333, SR48968, and SR142801, respectively (Fig. 2). In addition, each tachykinin receptor agonist was effective solely against the corresponding antagonist i.e., septide was without significant effect on

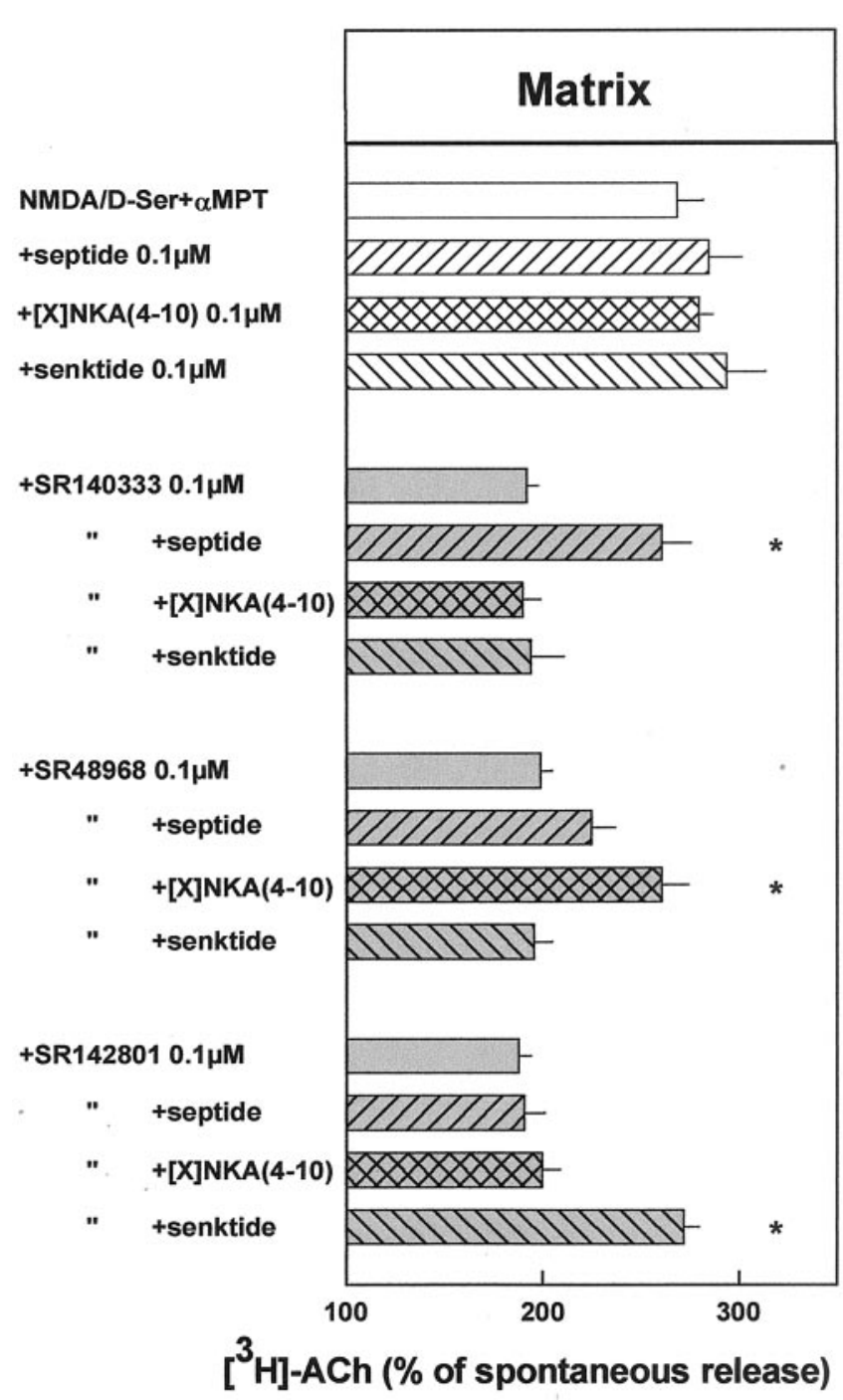

Figure 2. Selective suppression by $\mathrm{NK}_{1}, \mathrm{NK}_{2}$, and $\mathrm{NK}_{3}$ tachykinin agonists of the reduction of the NMDA-evoked release of $\left[{ }^{3} \mathrm{H}\right]-\mathrm{ACh}$ induced by corresponding tachykinin antagonists in the matrix. NMDA treatment was achieved under complete suppression of DA transmission with $\alpha$-MPT in the matrix. NMDA (1 mM $+10 \mu \mathrm{M}$ D-serine $)$ alone or with septide, $\left[\right.$ Lys $^{5}$, MeLeu $^{9}$, NLe $\left.^{10}\right]$ NKA(4-10) ([X]NKA(4-10)), or senktide was applied for $2 \mathrm{~min}, 70 \mathrm{~min}$ after the beginning of the washing period. $\alpha$-MPT $(100 \mu \mathrm{M})$ and, when used, SR140333, SR48968, or SR142801 were added to the ACSF from the start of the washing period up to the end of the experiment. Results are the means \pm SEM of data obtained in 7-15 experiments. ${ }^{*} p<0.05$ when the combined effects of NMDA and septide, $\left[\mathrm{Lys}^{5}, \mathrm{MeLeu}^{9}, \mathrm{NLe}^{10}\right] \mathrm{NKA}(4-10)$, or senktide in the presence of SR140333, SR48968, or SR142801, respectively, were compared with respective control responses obtained in the absence of the tachykinin agonists.

responses evoked by the $\mathrm{NK}_{2}(\mathrm{SR} 48968)$ and $\mathrm{NK}_{3}(\mathrm{SR} 142801)$ antagonists, $\left[\mathrm{Lys}^{5}{ }^{5}, \mathrm{MeLeu}^{9}, \mathrm{NLe}^{10}\right] \mathrm{NKA}(4-10)$ did not modify responses induced by the $\mathrm{NK}_{1}$ (SR140333) and $\mathrm{NK}_{3}$ (SR142801) antagonists and, finally, senktide was without effect on responses induced by either the $\mathrm{NK}_{1}$ (SR140333) or the $\mathrm{NK}_{2}$ (SR48968) antagonists (Fig. 2). These results demonstrate that the reductions by tachykinin receptor antagonists in ACh release evoked by NMDA stimulation are brought about by specific action of these antagonists at NK1, NK2, and NK3 receptors. 


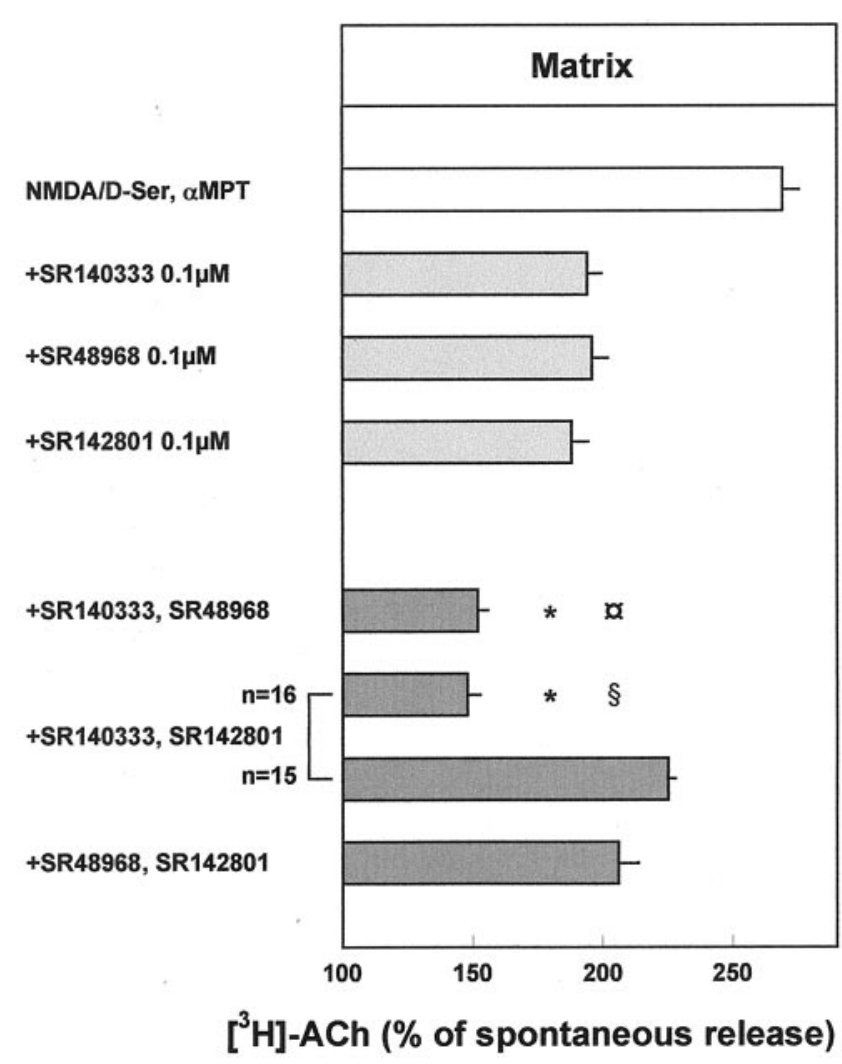

Figure 3. Effects of the combined application of tachykinin antagonists on the NMDA-evoked release of $\left[{ }^{3} \mathrm{H}\right]-\mathrm{ACh}$ in the matrix. NMDA treatment was achieved under complete suppression of DA transmission with $\alpha$-MPT. NMDA $(1 \mathrm{~mm}+10 \mu \mathrm{M}$ D-serine $)$ was applied for $2 \mathrm{~min}, 70 \mathrm{~min}$ after the beginning of the washing period. $\alpha$-MPT $(100 \mu \mathrm{M})$ and, when used, SR140333, SR48968, or SR142801 alone or in combination were added to the ACSF from the start of the washing period up to the end of the experiment. Results are the means \pm SEM of data obtained in 11-16 experiments. ${ }^{*} p<0.05$ when the effects of the NMDA treatment in the presence of combined application of SR140333 and either SR48968 or SR142801 were compared with the response of the NMDA treatment performed in the presence of SR140333 alone; $₫ p<0.05$ when the response of the NMDA treatment in the presence of combined application of SR140333 and SR48968 was compared with the response of the NMDA treatment in the presence of SR48968 alone; $\$ p<0.05$ when the response of the NMDA treatment in the presence of the combined application of SR140333 and SR142801 was compared with the response of NMDA treatment in the presence of SR142801 alone.

\section{Effects of combined applications of tachykinin receptor antagonists on the dopamine-independent NMDA-evoked release of $\left[{ }^{3} \mathrm{H}\right]-\mathrm{ACh}$ in the matrix}

The excitatory effects of endogenously released SP, NKA, and $\mathrm{NKB}$ on $\mathrm{ACh}$ release could be either direct or indirect depending on the localization of $\mathrm{NK}_{1}, \mathrm{NK}_{2}$, and $\mathrm{NK}_{3}$ receptors. Additional experiments were thus performed in the combined presence of tachykinin receptor antagonists (SR140333 with SR48968, SR140333 with SR142801, and SR48968 with SR142801; $0.1 \mu \mathrm{M}$ each) to determine whether endogenously released tachykinins act through distinct (additive responses) or common (no additive responses) processes.

As shown in Figure 3, the reduction of the NMDA + D-serine + $\alpha$-MPT-evoked release of $\left[{ }^{3} \mathrm{H}\right]-\mathrm{ACh}$ was much greater in the combined presence of SR140333 and SR48968 than in the presence of either the $\mathrm{NK}_{1}$ or the $\mathrm{NK}_{2}$ antagonist alone. In contrast, the effects of SR48968 and SR142801 were not additive because the reduction evoked by the coapplication of the two antagonists was identical to that induced by either the $\mathrm{NK}_{2}$ or the $\mathrm{NK}_{3}$ receptor antagonist alone. More complex effects were observed in the combined presence of SR140333 $\left(\mathrm{NK}_{1}\right)$ and SR142801 $\left(\mathrm{NK}_{3}\right)$ receptor antagonists. Indeed, in half of the experiments, the reduction of the NMDA-evoked release of $\left[{ }^{3} \mathrm{H}\right]-\mathrm{ACh}$ induced by both antagonists was much more prominent than that observed with each antagonist alone while this was not the case in other experiments (Fig. 3). Altogether these results suggest that the facilitatory effect of endogenously released SP is mediated by a mechanism that is distinct from that evoked by either NKA or $\mathrm{NKB}$, whereas a common process could be involved in the facilitatory response induced by NKA and NKB.

Effects of $N^{G}$-monomethyl-L-arginine on the tachykinin receptor antagonist-induced inhibition of the dopamine-independent release of $\left[{ }^{3} \mathrm{H}\right]-\mathrm{ACh}$ evoked by NMDA in the matrix

It has been shown in vitro that NO enhances membrane excitability of cholinergic interneurons through a direct postsynaptic action and that this effect, which is not secondary to the release of endogenous neurotransmitters, persists in the presence of dopamine or SP receptor antagonists (Centonze et al., 2001). In addition, it has also be reported in vivo that $\mathrm{NO}$ is involved in the facilitation of $\mathrm{ACh}$ release induced by the stimulation of $\mathrm{NK}_{2}$ tachykinin receptors (Steinberg et al., 1998b). Therefore, attempts were made to determine whether this is also the case in our in vitro conditions and whether differences or not can be observed under stimulation of $\mathrm{NK}_{1}, \mathrm{NK}_{2}$, or $\mathrm{NK}_{3}$ receptors. L-NMMA, a potent inhibitor of NO synthase (NOS) activity was used for this purpose. Experiments performed with L-NMMA in the absence of DA transmission indicated that, in the matrix, at a concentration of 1 $\mu \mathrm{M}, \mathrm{L}-\mathrm{NMMA}$ reduced by $31 \%$ the NMDA + D-serine $+\alpha$-MPTevoked release of $\left[{ }^{3} \mathrm{H}\right]-\mathrm{ACh}$, whereas no effect was observed at 0.1 $\mu \mathrm{M}$ (L-NMMA $1 \mu \mathrm{M}$ : +118 $\pm 5 \%$; L-NMMA $0.1 \mu \mathrm{M}:+183 \pm 8 \%$ vs control: $+171 \pm 6 \%$ of the spontaneous release).

As shown in Figure 4, whatever the concentration of L-NMMA $(0.1 \mu \mathrm{M}$ or $1 \mu \mathrm{M})$, the $\mathrm{NK}_{1}$ receptor antagonist (SR140333, $\left.0.1 \mu \mathrm{M}\right)$ still primarily inhibited the NMDA + D-serine $+\alpha$-MPT-evoked release of $\left[{ }^{3} \mathrm{H}\right]-\mathrm{ACh}$. In contrast, in the presence of $1 \mu \mathrm{M}$ L-NMMA, SR48968 $\left(\mathrm{NK}_{2}\right)$ and SR142801 $\left(\mathrm{NK}_{3}\right)$ no longer reduced the NMDA + D-serine $+\alpha$-MPT-evoked release of $\left[{ }^{3} \mathrm{H}\right]$ $\mathrm{ACh}$. Moreover, the suppression of the inhibitory effects of these tachykinin antagonists was already either partial (SR48968) or total (SR142801) when L-NMMA was used at a smaller concentration $(0.1 \mu \mathrm{M})$. These results suggest that the modulation of ACh release mediated by $\mathrm{NK} 2$ and $\mathrm{NK} 3$ receptors is dependent on NO.

\section{DISCUSSION}

The main findings of this study are that the marked increase of NMDA-evoked release of ACh observed after suppression of DA transmission is reduced by blockade of tachykinin receptors with specific antagonists in the matrix but not in the striosomes of the rat striatum. These data were obtained both in the acute absence of the DA inhibitory regulation [NMDA alone (NMDA) or with D-serine in the presence of $\alpha$-MPT (NMDA + D-serine + $\alpha$-MPT)] and after the chronic suppression of DA transmission (6-OHDA-induced degeneration of dopaminergic nigrostriatal neurons).

Endogenously released SP and NKA exert two opposite effects on the NMDA + D-serine-evoked release of ACh: a DAdependent inhibition occurring in both striatal compartments, 


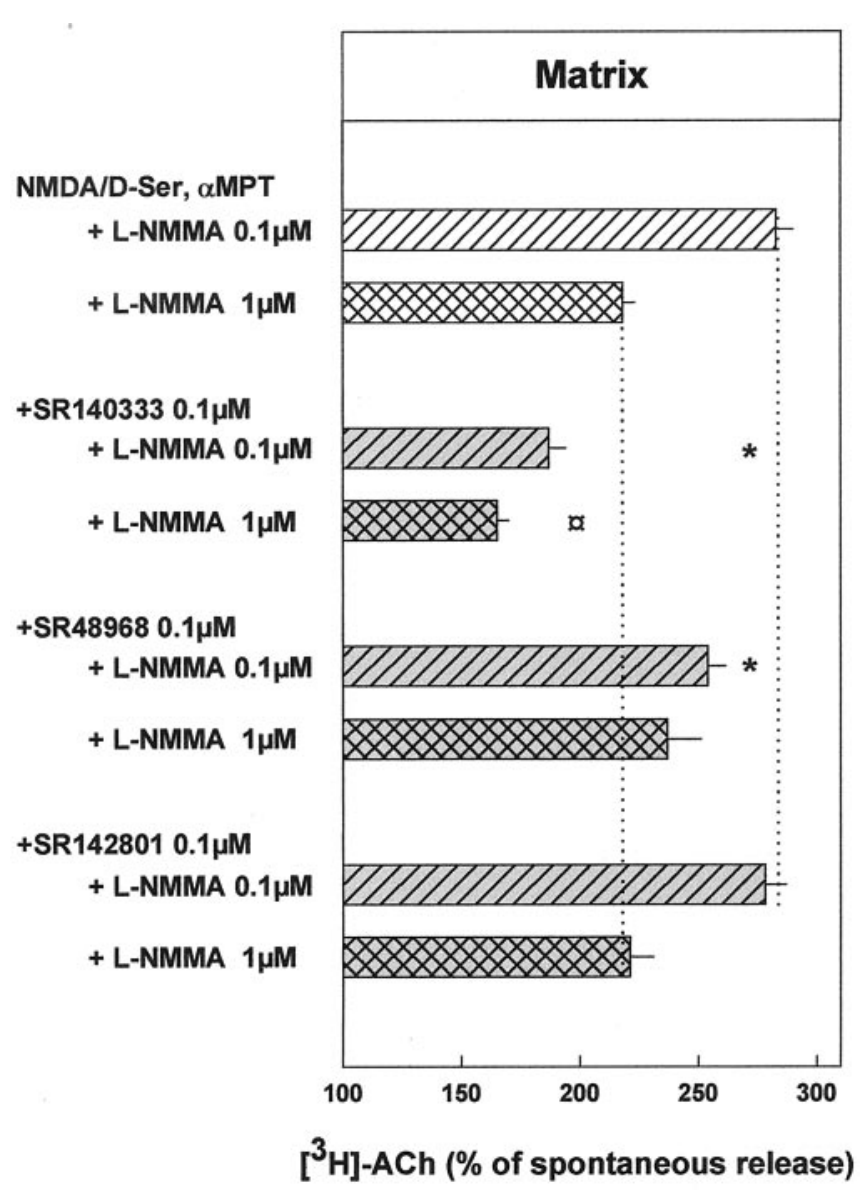

Figure 4. Effects of $N^{\mathrm{G}}$-monomethyl-L-arginine on the inhibition of the NMDA-evoked release of $\left[{ }^{3} \mathrm{H}\right]-\mathrm{ACh}$ induced by tachykinin receptor antagonists in the matrix. NMDA treatment was achieved under complete suppression of DA transmission with $\alpha$-MPT. NMDA $(1 \mathrm{mM}+10 \mu \mathrm{M}$ D-serine) was applied for $2 \mathrm{~min}, 70 \mathrm{~min}$ after the beginning of the washing period. $\alpha$-MPT $(100 \mu \mathrm{M}), N^{\mathrm{G}}$-monomethyl-L-arginine $(L-N M M A)$, and when used, SR140333, SR48968, or SR142801 were added to the ACSF from the start of the washing period up to the end of the experiment. Results are the means \pm SEM of data obtained in 13-26 experiments. ${ }^{*} p<0.05$ when responses of the NMDA treatment in the presence of the combined application of L-NMMA $(0.1 \mu \mathrm{M})$ and either SR140333 or SR48968 were compared with the response of the NMDA treatment in the presence of L-NMMA $(0.1 \mu \mathrm{M})$ alone; $\boldsymbol{\alpha} p<0.05$ when the response of the NMDA treatment in the presence of the combined application of L-NMMA $(1 \mu \mathrm{M})$ and SR140333 was compared with the response induced by the NMDA treatment in the presence of L-NMMA $(1 \mu \mathrm{M})$ alone.

whereas a DA-independent stimulation is observed only in the matrix (Blanchet et al., 1998). The present results confirm and extend these findings by several observations. (1) The reduction of NMDA responses induced in the matrix by the $\mathrm{NK}_{1}$ (SR140333) and $\mathrm{NK}_{2}$ (SR48968) antagonists occurred under complete suppression of DA transmission (NMDA + D-serine + $\alpha$-MPT) as well as with moderate release of DA (NMDA). (2) $\mathrm{NKB}$ is also involved in the regulation of the release of $\mathrm{ACh}$ in the matrix since the $\mathrm{NK}_{3}$ tachykinin receptor antagonist (SR142801) reduced the evoked release of ACh under the two acute conditions of reduced DA transmission. (3) The reductions of the evoked release of ACh induced by SR140333, SR48968, and SR142801 were of similar amplitude in the presence or absence of D-serine, suggesting that the amount of tachykinins released under NMDA alone is already sufficient to maximally facilitate the release of ACh. (4) The effects of SR140333,
SR48968, and SR142801 were specific because the corresponding inactive isomers were devoid of activity, and the inhibitory response of each of these antagonists could be selectively reversed by the corresponding $\mathrm{NK}_{1}, \mathrm{NK}_{2}$, and $\mathrm{NK}_{3}$ receptor agonists, septide, $\left[\mathrm{Lys}^{5}, \mathrm{MeLeu}^{9}, \mathrm{NLe}^{10}\right] \mathrm{NKA}(4-10)$, and senktide, respectively. (5) Finally, the inhibitory control of the NMDAevoked release of ACh induced by SR140333, SR48968, or SR142801 observed under the acute suppression of DA transmission, was found after chronic dopaminergic denervation, further demonstrating the physiological relevance of this regulation.

In our conditions in vitro, as under low neostigmine in vivo (DeBoer and Abercombie, 1996), a prevalent $\mathrm{D}_{2}$-mediated inhibition rather than an opposing $\mathrm{D}_{1}$-mediated stimulation of $\mathrm{ACh}$ release was found. Indeed, under potent stimulation of NMDA receptors, which markedly enhances the endogenous release of $\mathrm{DA}$, the $\mathrm{D}_{1}$ receptor-mediated stimulation of $\mathrm{ACh}$ release could only be observed in the matrix in the presence of a $\mathrm{D}_{2}$ receptor antagonist (Blanchet et al., 1997). Similarly, inhibitory responses of tachykinin receptor antagonists, SR140333, SR48968, and SR142801 on the evoked release of ACh were only found under low dopaminergic transmission in the matrix but not in the striosomes. Moreover, the facilitation of ACh release induced by neurotensin, which involves the action of endogenously released DA on $\mathrm{D}_{1}$ receptors, and which is suppressed by a $\mathrm{NK}_{2}$ antagonist, was only observed after $\mathrm{D}_{2}$ receptor blockade, i.e., in the absence of the DA inhibitory regulation (Steinberg et al., 1998b). However, the indirect facilitation of ACh release induced by the $\mathrm{D}_{1}$ receptor agonist (SKF38393), which involves $\mathrm{NK}_{1}$ (Anderson et al., 1994) and $\mathrm{NK}_{2}$ (Steinberg et al., 1998b) tachykinin receptors, did not require the presence of a $\mathrm{D}_{2}$ receptor inhibitor. This could result from the reduction of DA release triggers by local circuits occurring under the stimulation of $\mathrm{D}_{1}$ receptors (Acquas and Di Chiara, 1999). Finally, when DA transmission is reduced or $\mathrm{D}_{2}$-mediated inhibition is blocked, endogenously released SP, NKA, and NKB facilitate the release of ACh.

The diffusible messenger arachidonic acid facilitates indirectly the NMDA-evoked release of ACh in the striatum (Blanchet et al., 1999). This is also the case for NO that is formed in NOSsomatostatin-containing interneurons under NMDA receptor stimulation (Marin et al., 1992). Indeed, the competitive NOS inhibitor, L-NMMA, which decreases the NMDA-evoked release of NO (Luo et al., 1993), reduced the NMDA-evoked release of $\mathrm{ACh}$ in the matrix. There is already evidence in vitro that NO depolarizes cholinergic interneurons through a direct postsynaptic action which is independent of SP regulation (Centonze et al., 2001). In addition, in vivo, $\mathrm{NO}$ is involved in the $\mathrm{NK}_{2}$ but not the $\mathrm{NK}_{1}$ receptor-mediated facilitation of $\mathrm{ACh}$ release because the NKA- but not the septide-evoked release of ACh was abolished after NO synthesis inhibition (Steinberg et al., 1998b). In support of these observations, our results obtained in the matrix in the absence of DA transmission, indicate that the reduction of the NMDA-evoked release of ACh evoked by the $\mathrm{NK}_{2}$ antagonist, SR48968, is completely suppressed by L-NMMA while the reducing effect of the $\mathrm{NK}_{1}$ antagonist, SR140333, can still be observed (Fig. 5). Confirming the involvement of distinct mechanisms in the facilitatory effects of endogenous SP and NKA, the coapplication of SR140333 and SR48968 reduced to a much larger extent the NMDA + D-serine $+\alpha$-MPT-evoked release of ACh than the application of SR140333 or SR48968 alone. It cannot be excluded that SP and NKA, which share common precursors (Krause et al., 1987), are released, at least partly, from different nerve terminals because of differential processing of these precursors and address- 


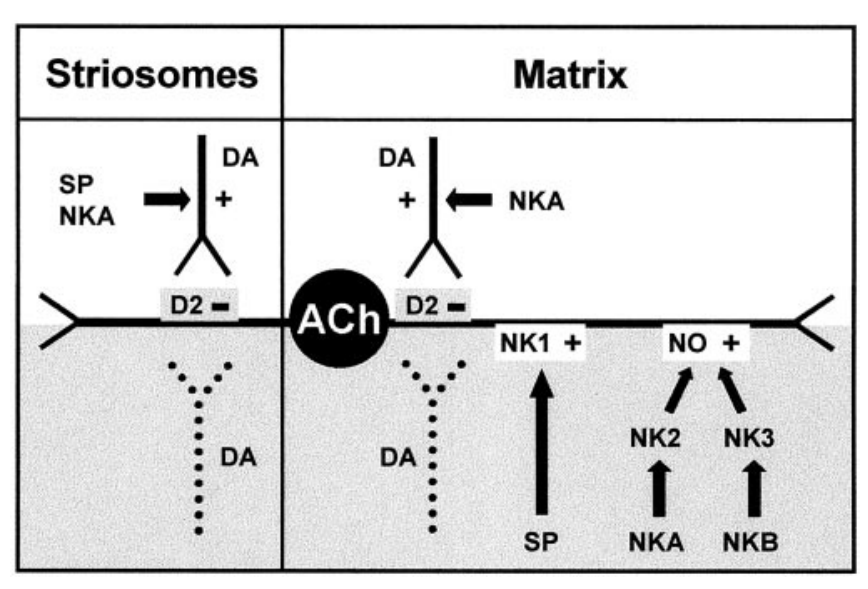

Figure 5. Schematic representation of the tachykinergic regulation of the NMDA-evoked release of ACh in the presence and absence of dopaminergic transmission in the striosomes and the matrix of the rat striatum. Cholinergic interneurons ( $\mathrm{ACh}$ ) whose cell bodies are mainly located in the matrix innervate both striatal compartments. Top, In the presence of dopaminergic transmission, endogenously released substance $\mathrm{P}(S P)$ and neurokinin $\mathrm{A}(N K A)$ in striosomes and NKA in the matrix indirectly inhibit the evoked release of ACh through a dopamine $(D A)$-dependent process. More precisely, endogenously released tachykinins facilitate the release of DA, which in turn inhibits the release of ACh by acting on D2 receptors located on cholinergic interneurons (Blanchet et al., 1998). Bottom, After acute or chronic suppression of dopaminergic transmission, endogenously released SP, NKA, and NKB facilitate the evoked release of ACh in the matrix but not in the striosomes. The SP response is nitric oxide $(N O)$-independent and mediated by NK1 receptors located on cholinergic interneurons. NKA and NKB responses are NO-dependent and mediated through NK2 and NK3 receptors. The activation of these receptors facilitates the release of $\mathrm{NO}$, which in turn directly stimulates the activity of cholinergic interneurons.

ing of these peptides. More probably, the additivity of the SP and NKA responses results from their respective action on $\mathrm{NK}_{1}$ and $\mathrm{NK}_{2}$ receptors distributed on distinct cells. Because NK1 receptors are densely located on cholinergic interneurons (Gerfen, 1991; Kaneko et al., 1993; Jakab et al., 1996), and because SP induces potent depolarization of these interneurons (Aosaki and Kawaguchi, 1996) stimulation of these NK1 receptors by endogenously released SP may greatly contribute to the DA-independent facilitation of the NMDA-evoked release of ACh (Fig. 5). However, the additional intervention of presynaptic $\mathrm{NK}_{1}$ receptors present on afferent striatal fibers (Jakab and Goldman-Rakic, 1996) cannot be excluded. There is now direct evidence for the presence of $\mathrm{NK}_{2}$ receptors in some brain structures (Steinberg et al., 1998a), but these receptors have not yet been identified in the striatum. Because of the main contribution of NO in the NKA response, the $\mathrm{NK}_{2}$ receptors involved in this regulation could be located on NOS-somatostatin-containing interneurons.

The DA-independent facilitation of the NMDA-evoked release of ACh by endogenously released NKB is also mediated by NO. Indeed, as with the $\mathrm{NK}_{2}$ antagonist, SR48968, the reduction of the NMDA response induced by the $\mathrm{NK}_{3}$ antagonist, SR142801 disappeared under the L-NMMA treatment. In addition, the nonadditivity of the effects of SR48968 and SR142801 further indicates that NKA and NKB act through a common process (Fig. 5). Moreover, the identification of $\mathrm{NK}_{3}$ receptor mRNAs in NOS-somatostatin-containing interneurons (Preston et al., 2000) provides complementary evidence for the involvement of NO in the NKB response. However, surprisingly, additive inhibitory responses of SR140333 and SR142801 were only observed in half of the experiments. Because SP and NKB are localized on distinct efferent neurons, and because NKB-positive cells mainly located in the lateral part of the striatum are arranged in clusters (Marksteiner et al., 1992), these peptides could be partly released in different matrix areas. Although the additive responses likely occurred when the superfusion was precisely located in a matrix area possessing both SP- and NKB-containing nerve terminals, this could explain the nonadditive effects of SR140333 and SR142801 in half of the experiments and provide further evidence for the functional heterogeneity of the matrix (Malach and Graybiel, 1988; Kemel et al., 1992).

In conclusion, using the selective $\mathrm{NK}_{1}, \mathrm{NK}_{2}$, and $\mathrm{NK}_{3}$ tachykinin receptor antagonists, SR140333, SR48968, and SR142801, respectively (Emonds-Alt et al., 1992, 1993, 1995), our study indicates that endogenous tachykinins, SP, NKA, and NKB are released from collaterals of striatal efferent neurons after stimulation of NMDA receptors. In the matrix, SP, NKA, and NKB facilitate the NMDA-evoked release of $\mathrm{ACh}$ and these effects only occur and/or are unmasked after either acute or chronic suppression of dopaminergic transmission. Although the SPinduced facilitation of $\mathrm{ACh}$ seems to be a direct process involving $\mathrm{NK}_{1}$ receptors located on cholinergic interneurons, the NKAand NKB-induced facilitations are mediated by NO. Therefore, in the matrix, tachykinins present in efferent GABAergic neurons from both the direct (NKA and SP) and indirect (NKB) pathways of the basal ganglia can contribute to the DA-independent facilitatory regulation of the evoked release of ACh.

Several modifications of neuropeptide levels have been observed in the striatum after degeneration of dopaminergic neurons (Agid and Javoy-Agid, 1985; Gerfen et al., 1990; Graybiel, 1990; De Ceballos and Lopez-Lozano, 1999). These changes in peptide synthesis and/or neurotransmission could be directly or indirectly responsible for some of the functional dysregulations associated with striatal dopamine deficiency and activation of the cholinergic interneurons. According to our findings, $\mathrm{NK}_{1}, \mathrm{NK}_{2}$, and $\mathrm{NK}_{3}$ tachykinin receptor antagonists alone or combinations of the $\mathrm{NK}_{1}$ antagonist with either the $\mathrm{NK}_{2}$ or $\mathrm{NK}_{3}$ antagonists that induce more potent reduction of cholinergic transmission could be appropriately used as indirect cholinergic antagonists in the treatment of Parkinson's disease. Such a therapeutic strategy could ameliorate the mental state of Parkinson's patients because there is evidence that these tachykinin receptor antagonists, $\mathrm{NK}_{1}$ antagonists particularly, exert an antidepressant action (Rupniak and Kramer, 1999).

\section{REFERENCES}

Acquas E, Di Chiara G (1999) Dopamine D(1) receptor-mediated control of striatal acetylcholine release by endogenous dopamine. Eur J Pharmacol 383:121-127.

Agid Y, Javoy-Agid F (1985) Peptides and parkinson's disease. Trends Neurosci 8:30-35.

Anderson JJ, Kuo S, Chase TN, Engber TM (1994) Dopamine $\mathrm{D}_{1}$ receptor-stimulated release of acetylcholine in rat striatum is mediated indirectly by activation of striatal neurokinin ${ }_{1}$ receptors. J Pharmacol Exp Ther 269:1144-1151.

Anderson JJ, Randall S, Chase T (1995) The neurokinin1 receptor antagonist CP-99,994 reduces catalepsy produced by the dopamine D2 receptor antagonist raclopride: correlation with extracellular acetylcholine levels in striatum. J Pharmacol Exp Ther 274:928-936.

Aosaki T, Kawaguchi Y (1996) Actions of substance P on rat neostriatal neurons in vitro. J Neurosci 16:5141-5153.

Aosaki T, Kimura M, Graybiel AM (1995) Temporal and spatial characteristics of tonically active neurons of the primate's striatum. J Neurophysiol 73:1234-1252.

Arenas E, Alberch J, Perez-Navarro E, Solsona C, Marsal J (1991) Neurokinin receptors differentially mediate endogenous acetylcholine release evoked by tachykinins in the neostriatum. J Neurosci 11:2332-2338. 
Bernard V, Dumartin B, Lamy E, Bloch B (1993) Fos immunoreactivity after stimulation or inhibition of muscarinic receptors indicates anatomical specificity for cholinergic control of striatal efferent neurons and cortical neurons in the rat. Eur J Neurosci 5:1218-1225.

Besson MJ, Graybiel AM, Quinn B (1990) Co-expression of neuropeptides in the cat's striatum: an immunohistochemical study of substance $\mathrm{P}$, dynorphin B and enkephalin. Neuroscience 39:33-58.

Blanchet F, Kemel ML, Gauchy C, Desban M, Perez S, Glowinski J (1997) $N$-methyl-D-aspartate-evoked release of $\left[{ }^{3} \mathrm{H}\right]$-acetylcholine in striatal compartments of the rat: regulatory roles of dopamine and GABA. Neuroscience 81:113-127.

Blanchet F, Gauchy C, Perez S, Soubrié P, Glowinski J, Kemel ML (1998) Distinct modifications by neurokinin $_{1}$ (SR140333) and neurokinin 2 (SR48968) tachykinin receptor antagonists of the $N$-methyl-DAspartate-evoked release of acetylcholine in striosomes and matrix of the rat striatum. Neuroscience 85:1025-1036.

Blanchet F, Gauchy C, Perez S, Glowinski J, Kemel ML (1999) Role of arachidonic acid in the regulation of the NMDA-evoked release of acetylcholine in striatal compartments. Synapse 31:140-150.

Blanchet F, Gauchy C, Perez S, Soubrié P, Glowinski J, Kemel ML (2000) Control by GABA and tachykinins of the evoked release of acetylcholine in striatal compartments under different modalities of NMDA receptor stimulation. Brain Res 853:142-150.

Bolam JP, Bennett BD (1995) Microcircuitry of the neostriatum. In: Molecular and cellular mechanisms of neostriatal function (Ariano MA, Surmeier DJ, Eds), pp 1-19. Austin, TX: Landes.

Calabresi P, Centonze D, Gubellini P, Pisani A, Bernardi G (2000) Acetylcholine-mediated modulation of striatal function. Trends Neurosci 23:120-126.

Centonze D, Pisani A, Bonsi P, Giacomini P, Bernardi G, Calabresi P (2001) Stimulation of nitric oxide-cGMP pathway excites striatal cholinergic interneurons via protein kinase $G$ activation. J Neurosci 21:1393-1400

Darracq L, Drouin C, Blanc G, Glowinski J, Tassin JP (2001) Stimulation of metabotropic but not ionotropic glutamatergic receptors in the nucleus accumbens is required for the D-amphetamine-induced release of functional dopamine. Neuroscience 103:395-403.

DeBoer P, Abercrombie E (1996) Physiological release of striatal acetylcholine in vivo: modulation by D1 and D2 dopamine receptor subtypes. J Pharmacol Exp Ther 277:775-783.

De Ceballos ML, Lopez-Lozano JJ (1999) Subgroups of parkinsonian patients differentiated by peptidergic immunostaining of caudate nucleus biopsies. Peptides 20:249-257.

Desban M, Kemel ML, Glowinski J, Gauchy C (1993) Spatial organization of patch and matrix compartments in the rat striatum. Neuroscience 57:661-671.

Emonds-Alt X, Vilain P, Goulaouic P, Projetto V, Van Broeck D, Advenier C, Naline E, Neliat G, Le Fur G, Brelière JC (1992) A potent and selective non-peptide antagonist of the neurokinin $\mathrm{A}\left(\mathrm{NK}_{2}\right)$ receptor. Life Sci 50:101-106.

Emonds-Alt X, Doutremepuich JD, Heaulme M, Neliat G, Santucci V, Steinberg R, Vilain P, Bichon D, Ducoux JP, Projetto V, Van Broeck D, Soubrié P, Le Fur G, Brelière JC (1993) In vitro and in vivo biological activities of SR140333, a novel potent non-peptide tachykinin NK1 receptor antagonist. Eur J Pharmacol 250:403-413.

Emonds-Alt X, Bichon D, Ducoux JP, Heaulme M, Miloux B, Poncelet M, Proietto V, Van Broeck D, Vilain P, Neliat G, Soubrié P, Le Fur G, Brelière JC (1995) SR142801, the first potent non-peptide antagonist of the tachykinin NK3 receptor. Life Sci 56:27-32.

Gerfen CR (1991) Substance P (neurokinin-1) receptor mRNA is selectively expressed in cholinergic neurons in the striatum and basal forebrain. Brain Res 556:165-170.

Gerfen CR, Wilson CJ (1996) The basal ganglia. In: Handbook of chemical neuroanatomy, Integrated systems of the CNS, Part III, Vol 12 (Swanson LW, Bjorklund A, Hokfelt T, eds), pp 371-468. Amsterdam: Elsevier.

Gerfen CR, Engber TM, Mahan LC, Susel Z, Chase TN, Monsma Jr FJ, Sibley DR (1990) D1and D2 dopamine receptor regulated gene expression of striatonigral and striatopallidal neurons. Science 250:1429-1432.

Graybiel AM (1990) Neurotransmitters and neuromodulators in the basal ganglia. Trends Neurosci 13:244-254

Graybiel AM, Baughman RW, Eckenstein F (1986) Cholinergic neuropil of the striatum observes striosomal boundaries. Nature 323:625-627.

Guevara-Guzman R, Kendrick KM, Emson PC (1993) Effect of sub- stance $\mathrm{P}$ on acetylcholine and dopamine release in the rat striatum: a microdialysis study. Brain Res 622:147-154.

Herkenham M, Pert CB (1981) Mosaic distribution of opiate receptors, parafascicular projections and acetylcholinesterase in rat striatum. Nature 291:415-417.

Jakab RL, Goldman-Rakic P (1996) Presynaptic and postsynaptic subcellular localization of substance $\mathrm{P}$ receptor immunoreactivity in the eostriatum of the rat and Rhesus monkey (Macaca mulatta). J Comp Neurol 369:125-136.

Jakab RL, Hazrati L, Goldman-Rakic P (1996) Distribution and neurochemical character of substance $\mathrm{P}$ receptor (SPR)-immunoreactive striatal neurons of the macaque monkey: accumulation of SP fibers and SPR neurons and dendrites in "striocapsules" encircling striosomes. J Comp Neurol 369:137-149.

Kaneko T, Shigemoto R, Nakanishi S, Misumo N (1993) Subtance P receptor-immunoreactive neurons in the rat neostriatum are segregated into somatostatinergic and cholinergic aspiny neurons. Brain Res 631:297-303.

Kemel ML, Desban M, Glowinski J, Gauchy C (1992) Functional heterogeneity of the matrix compartment in the cat caudate nucleus as demonstrated by the cholinergic presynaptic regulation of dopamine release. Neuroscience 50:597-610.

Krause JE, Chirgwin JM, Carter MX, Xu ZS, Hershey AD (1987) Three rat preprotachykinin mRNAs encode the neuropeptides substance $\mathrm{P}$ and neurokinin A. Proc Natl Acad Sci USA 84:881-885.

Krebs MO, Trovero F, Desban M, Gauchy C, Glowinski J, Kemel ML (1991) Distinct presynaptic regulation of dopamine release through NMDA receptors in striosome- and matrix-enriched areas of the rat striatum. J Neurosci 11:1256-1262.

Luo D, Knezevich S, Vincent SR (1993) $N$-methyl-D-aspartate-induced nitric oxide release: an in vivo microdialysis study. Neuroscience 57:897-900

Malach R, Graybiel AM (1988) Mosaic architecture of somatic sensoryrecipient sector of the cat's striatum. J Neurosci 6:3436-3458.

Marin P, Lafon-Cazal M, Bockaert J (1992) A nitric oxide synthase selectively stimulated by NMDA receptors depends on protein kinase $\mathrm{C}$ activation in mouse striatal neurons. Eur J Neurosci 4:425-432.

Marksteiner J, Saria A, Krause JE (1992) Comparative distribution of neurokinin B-, substance P- and enkephalin-like immunoreactivities and neurokinin B messenger RNA in the basal forebrain of the rat: evidence for neurochemical compartmentation. Neuroscience 51:107-120.

Olanow CW, Koller WC (1998) An algorithm (decision tree) for the management of Parkinson's disease: treatment guidelines. Neurology 50:S1-S57.

Paxinos G, Watson C (1986) The rat brain in stereotaxic coordinates. Australia: Academic.

Petitet F, Glowinski J, Beaujouan JC (1991) Evoked release of acetylcholine in the rat striatum by stimulation of tachykinin $\mathrm{NK}_{1}$ receptors. Eur J Pharmacol 192:203-204.

Preston Z, Richardson PJ, Pinnock RD, Lee K (2000) NK-3 receptors are expressed on mouse striatal gamma-aminobutyric acid-ergic interneurones, evoke [(3)H]gamma-aminobutyric acid release. Neurosci Lett 284:89-92.

Rupniak NM, Kramer MS (1999) Discovery of the antidepressant and anti-emetic efficacy of substance $\mathrm{P}$ receptor (NK1) antagonists. Trends Pharmacol Sci 20:485-490.

Scatton B, Lehmann J (1982) N-methyl-D-aspartate-type receptors mediate striatal ${ }^{3} \mathrm{H}$-acetylcholine release evoked by excitatory amino acids. Nature 297:422-424.

Steinberg R, Rodier D, Souilhac J, Bougault I, Emonds-Alt X, Soubrié P, Le Fur G (1995) Pharmacological characterization of tachykinin receptors controlling acetylcholine release from rat striatum: an in vivo microdialysis study. J Neurochem 65:2543-2548.

Steinberg R, Marco N, Voutsinos B, Bensaid M, Rodier D, Souilhac J, Alonso R, Oury-Donat F, Le Fur G, Soubrié P (1998a) Expression and presence of septal neurokinin-2 receptors controlling hippocampal acetylcholine release during sensory stimulation in rat. Eur $\mathbf{J}$ Neurosci 10:2337-2345.

Steinberg R, Souilhac J, Rodier D, Alonso X, Emonds-Alt X, Le Fur G, Soubrié P (1998b) Facilitation of striatal acetylcholine release by dopamine D1 receptor stimulation: involvement of enhanced nitric oxide production via neurokinin-2 receptor activation. Neuroscience 84:511518. 